\title{
David Ausubel's Theory and Learning Improvement: A Case Study of the Leveling Courses Program in Basic Sciences for Engineering
}

\author{
Pedro Santos Valente* \\ *Instituto de Tecnologia, Universidade Federal do Pará, Belém, Brasil. \\ E-mail: pedrosv2010@hotmail.com. \\ José Benício da Cruz Costa \\ •Instituto de Tecnologia, Universidade Federal do Pará, Belém, Brasil. \\ E-mail: benicio@ufpa.br. \\ Gilberto Martins Lynch^ \\ ^Instituto de Tecnologia, Universidade Federal do Pará, Belém, Brasil. \\ E-mail: gilbertolynch2020@gmail.com. \\ Douglas da Silva Barros" \\ 'Instituto de Tecnologia, Universidade Federal do Pará, Belém, Brasil. \\ E-mail: dasilvabarros.douglas1@gmail.com.
}

\begin{abstract}
Various Universities in Brazil and the world face an evasion situation from their students. Moreover, the Engineering courses suffer from this same dilemma. The number of students that drop out Higher Education is highly relevant and connected to social, economic and academic losses. Trying to soften this problem the Department of Extension of the Universidade Federal do Pará
\end{abstract}


(UFPA) created the Levelling Courses Program in Basic Sciences for Engineering (LCPBSE) in 2011. Teaching the basic content of Mathematics, Physics and Chemistry is the main front of the program. The classes are taught to the new undergraduate students, even before they had contact with the subjects from the basic cycle, such as Calculus 1. The LCPBSE reinforces the fundamental topics teaching to the elementary subjects from the Engineering courses. This makes it fulfill the function of reducing the educational gaps in the conceptual and operational fields of the basic sciences, accordingly statistical studies. Considering the program as a tool against evasion, this paper aims the better understanding of how it works and comprehend how it was capable of raising the approval rates in the initial disciplines. In other words, this research focus on understand the epistemological learning mechanism that is connected to the increasing in students' academic performance. Our methodology was the bibliographic research through some theorists who study the cognitive learning. We analyzed the authors Piaget, Vygotsky, Kelly, Ausubel and Vergnaud. As result of the bibliographic survey, we verified that David Ausubel proposes the Meaningful Learning Theory, which can explain how the LCPBSE students are learning in a more effective way. According Ausubel it is necessary that the new information relates with some knowledge already existent in the apprentice's cognitive structure, in order to the learning occurs not in a mechanical way, but in a meaningful way. This relevant information are called as subsumers, which are anchors to the new knowledge to be acquired. Using this theory as foundation, the classes taught by the LCPBSE can be acting as organizers and developers of these subsumers, permitting the students to enroll Calculus courses already provided with the necessary prior knowledge. Ultimately, we conclude that one of the possible strategies to improve the learning and combat the evasion can be the subsumers development. This strategy is not limited to LCPBSE, but it can be also applied in another Universities programs.

Keywords: Meaningful Learning, David Ausubel, Engineering, Evasion, Subsumers.

\section{Introduction}

According the calculation based on the data given by the Instituto Nacional de Estudos e Pesquisas Educacionais Anísio Teixeira (INEP), the average annual rate of Brazilian Higher Education evasion, during 2001 to 2005, was $22 \%^{1}$. Analyzing this percentage and considering that the quantity of enrolled registrations in 2008 was 5.080 .056 students $^{2}$, we verify that $22 \%$ of 5.080 .056 is equivalent to 1.117 .612 . Which means that more than 1 million of academics have given up to proceed the Higher Education in the referred year of $2008^{3}$.

Comparing this reality with another countries, it is possible to confirm that exists a high evasion rate in an international level. In the years of 2005 and 2006 , countries like Colombia got $51 \%$ of evasion while Chile reached levels of $54 \%{ }^{1}$. What shows that this problem is not a local challenge, but one that surpass borders, affecting institutions from different parts of the world. And the Engineering courses are not exempt of this reality.

The Higher Education drop-out represents a loss in several aspects. There is a loss of financial resources by the Universities, once they invest capital to the professional capacitation, which will not have proper return and will be lost as the students don't conclude their graduation ${ }^{4}$. There is a loss of invested time by the students, which could be better used There is also a loss to the society, because it will have a less quantity of Engineering with full education, who could be contributing to the construction and development of the place they would act.

The evasion is not occasioned by just one factor, but there are many questions contributing to its occurrence ${ }^{5}$. It can happen due to the low quality of basic education, which 
not guarantee the candidates' competence to the third level education. The early pick of the professional specialty, in consideration of the large quantity of courses, also can be another factor. The financial difficulties paying the graduation expenses also can contribute. There are further questions as the lack of adaptation, lack of familiar support and little integration between student and institution ${ }^{5}$.

Trying to minimize this problem, the Instituto de Tecnologia (ITEC) of the Universidade Federal do Pará (UFPA) created in 2011 the Levelling Courses Program in Basic Sciences for Engineering (LCPBSE), which performance consists in attenuate the basic difficulties from a freshman of college. Among the various factors that influence on the drop-out, the program works on the one related to the deficient quality of basic education.

\section{LCPBSE Performance}

As the general goal this program objectify to reinforce the Basic Sciences formation of the Engineering students in UFPA, in way to provide better academic performances, as well as guarantee the curricular integration in enabled time and a more effective teachinglearning process, aiming a greater quality in the formation of the graduated professional by the ITEC/UFPA.

In order to the planned goals be reached, many methodologic resources are used, as well as integration strategies between teaching-research-extension, among them: introductory, expository and/or preparatory classes; conceptual lists; problems and exercises; problemsituation; exercises classes; seminaries realization; and questions duty.

Among these strategies, the main action front consists in giving expository lectures of elementary Mathematics, Physics and Chemistry, to guarantee that the students who didn't have an efficient educational foundation can mitigate their difficulties and upgrade their knowledge. These classes are taught ahead the first graduation classes. They will suit as a foundation to the learning of contents like Calculus I, for an example.

The leveling courses are ministered in three weeks, from Monday to Friday, from 8 a.m. until 6 p.m., with a break from 12 p.m. to 2 p.m. for lunch. It is offered 4 class periods, and each period has a two hours duration. The Mathematics, Physics and Chemistry classes are structured in an interleaved mode. Physics and Chemistry include theoretical and practical classes, while Mathematics count with just theoretical classes.

Statistical studies have been showing that the LCPBSE is achieving a relevant role helping the students' achievement in initial subjects from college. The approval percentage from those who went through the leveling course is higher than the one from those who didn't. Nevertheless, it is still unknown how to explain the Program success. It is still unknown which epistemological mechanism has been used to achieve such results.

In such a manner, recognizing the LCPBSE importance as a fundamental tool against the evasion rate, this research seeks to understand the program functionality and how it was capable of increasing the approval indexes. Thus, this paper has the objective of explaining how the LCPBSE support the students and it looks forward to understand the epistemological mechanism behind the factors that contribute to the increase of students' academic performance.

\section{Methodology}

Along the intent of finding some theory that explain how the LCPBSE is able to help the students yield in the subjects of Calculus, we realized a bibliographic research among scholars who study the process of teaching-learning and the human cognition. In this knowledge 
field there are three predominant philosophical approaches: Behaviorism, Cognitivism and Humanism.

In the Behaviorism Philosophy, the emphasis is the observable behaviors. The desired learnings, those that the students should learn, are expressed in terms of observable behaviors. The evaluation consists in verify if the defined conduct on the behavioral objectives are, in fact, presented at the end of the instruction. If this happens, it is implicitly admitted that the learning occurred. A basic idea of this philosophy is that the behavior can be controlled by the subsequent consequences of the answer given by the student ${ }^{6}$. Some of the authors who belong to this philosophic movement are: Pavlov, Watson, Guthrie, Thorndike e Skinner.

In the Cognitivism Philosophy, the emphasis is the cognition, the action of recognize. The central aspect is no longer the observable behavior, but the analysis of the aspects which interfere the stimulus and answer process. The focus is to understand the superior mental processes, in other words, the process of comprehension, transformation, storage and use of information involved in the cognition plan. The Cognitivism occupies in the attribution of meanings. In the education, this approach implies to quit seeing the student as a knowledge receptor, not important how the student storage it and organize it in its mind. The student starts to be considered as a construction agent, which is its own cognitive structure ${ }^{7}$. Piaget, Vygotsky, Kelly, Ausubel e Vergnaud are some representatives of this philosophic approach.

The emphasis of the Humanism Phylosophy is the being that learns, which is seen as a whole, considering feelings, thoughts and actions. The learning is not limited to the increase of knowledge, but even the self-realization and growth questions gain relevance. This kind of orientation made the "student centered teaching" arose, which had given more freedom of choice to the student, and the pedagogy of liberation, which defends an education that dialogues, problematizes and stimulates the apprentice's criticism and autonomy ${ }^{7}$. Carl Rogers e Paulo Freire are some examples of humanists theorists.

This current paper doesn't seek to emphasize the behavioral question neither the human question, but pursue to understand the students' mental processes. Therefore, it was chosen to study the theorists that have a Cognitivist Philosophy approach, in other words, it was made a bibliographic survey of the ideas by Jean Piaget, Lev Vygotsky, George Kelly, Gerard Vergnaud and David Ausubel, once they developed learning theories focused on the cognition. While they were developing their theories some of this authors were not using learning as a central concept, Piaget for an example, concentrates on the cognitivist development. However, his principles have great implication to understand the teaching-learning process.

\section{Learning Theories}

Piaget defines four general periods to the Cognitive Development that goes since birth until adult life: sensorimotor, preoperational, concrete operational and formal operational. He also presents the concepts of assimilation, accommodation and equilibrium, in addition to explain the "higher equilibrium" process and reversible teaching as fundamental steps of learning ${ }^{8}$.

To Vygotsky, the Cognitive Development is given by the interiorization of instruments and sign systems that were culturally produced. In his analysis, all the higher mental functions are originated as relations between human beings. Thus, the social interaction is the fundamental transport to the dynamic transmission (from inter to intrapersonal) of the social, historical and culturally built knowledge ${ }^{9}$.

George Kelly presents the concept of construct as being a representation of the Universe 
or a part of it, a portrayal made by a living creature and then tested against the reality. In other words, the man sees the world by means of molds, standards, templates, which are constructed to give sense to the Universe realities. Kelly name these molds as constructs ${ }^{10}$.

Vergnaud developed the Theory of Conceptual Fields. According him, Conceptual Field is a group of problems and situations that the treatment requires concepts, procedures and representations of different kinds, but intimately related. Some of the keys concepts to his theory are scheme, situation and operative invariant ${ }^{11}$.

David Ausubel focus his attention on the learning, such as how it happens in the classroom in the daily basis in the majority of schools. He developed the Meaningful Learning Theory, which has its central idea based on the following principle: the most important isolated factor that has influence over the learning is what the apprentice already knows, find what they know and establish that on the teaching. In his work, he made the distinction between Mechanic Learning and Meaningful Learning ${ }^{12}$.

Among the studied theories and authors, we verified that the Meaningful Learning by David Ausubel has aspects that are related to what LCPBSE has been doing. The ministered classes by the Program can be developing the needed previous knowledges in a way to significantly learn the Calculus subjects. Accordingly Ausubel's words the classes could be differentiating the students' subsumers.

Having in note that this theory includes ideas that are related to the action fronts from the LCPBSE, and that it can help to understand the Program's functionality and action. This present work is concentrated from now on in explaining the Meaningful Learning Theory by David Ausubel, relating its ideas to the developed activities by LCPBSE.

\section{Meaningful Learning Theory by David Ausubel}

Meaningful Learning is the process where with a new information interacts in a substantive and non-arbitrary way with what the students already know. It is the process where with the symbolically expressed ideas are connected with a specifically relevant aspect of the cognitive structure from the individual, in other words, this process consists in the interaction between the new information and a structure of a specific knowledge already existing ${ }^{13}$.

When Ausubel says that the interaction is substantive, it means that it is not literal. And when he stated that it is non-arbitrary, it means that the interaction is not formed with any previous idea, but with some specific knowledge, which is relevant and is already existing in the cognitive structure. David Ausubel names this knowledge as subsumer, which can be a concept, a proposition, a mental model, an image or a significant symbol, for an example ${ }^{14}$.

To exemplify what a subsumer is, we could take the force concept already existing in the apprentice's cognitive structure. In school these students learn that there is in nature another kind of force that is related to the objects mass: the gravitational force. They learn that this force is very important to conduct the Planetary System; it is from attractive nature; and it is governed by certain law. However, to give some significance to this new kind of force the individual probably uses the subsumer of force already existing in their own cognitive structure.

Therefore, the subsumers have the function to attribute meaning to new information, in a way that the learning will be really meaningful. This meanings attribution occur by intermediation of this interaction, just like the subsumers work as anchors to the new knowledge that will be assimilated, in order they can be associated to the previous knowledges.

In this anchorage process besides to attribute meaning to the new information, the subsumers also acquire new meanings and go through a stage of growth and modification. While 
the subsumer achieve new meanings, it gets richer, more elaborated and more stable. In the previous example, the force concept was expanded, because now the student understands that this force can have an attractive nature and can be applied to long distances. Therefore, the force subsumer got clearer, more differentiated and more omnibus ${ }^{15}$.

This means that the existing subsumers in the cognitive structure can be embracing and well-developed or limited and poor developed. Which means they can be more or less differentiated, depending on the frequency that the Meaningful Learning happens in conjunction with a subsumer data. For an example, the student will be able to be in touch with the electromagnetic force concept, and expand its force concept, because now they will know that the force can act in a repulsive nature and no longer in an attractive one like the case of gravitational force. Thus, the initial subsumer gets more elaborated and become more inclusive, which means it is more able to work as an anchor to another relative information to force or correlates.

\subsection{Mechanic Learning Versus Meaningful Learning}

Opposite to the Meaningful Learning, Ausubel evidences the Mechanic Learning. As part of it, a new information learning occurs with little or no interaction with relevant concepts existing in the cognitive structure ${ }^{16}$. In this situation, the acquired knowledge is storage in arbitrary way, without connection with specific subsumers. It is a process of instruction without meaning and that doesn't require comprehension. For an example, the learning of pair of syllables without any meaning to children. However, there is also the simple memorization of formulas, laws and concepts that can be taken as examples to the Mechanic Learning, just like the children have been doing to assimilate the syllables.

Ausubel doesn't specify a distinction between Meaningful and Mechanic Learning as being a dichotomy, but as a continuum. Thus, the transition from one kind of learning to another doesn't happen in a natural or automatic way, but it takes some conditions in consideration. The Meaningful Learning is progressive, in a way that the subsumer construction is a process of catchment, internalization, differentiation and reconciliation of meanings, which is not immediate. The Meaningful Learning depends on the meanings catchment and not just on the literal storage of ideas as happens on the Mechanic Learning.

Once noticed that the Meaningful Learning presupposes the previous existence of subsumers, what to do when they do not exist? Where are these subsumers from and how do they form?

Actually, the Mechanic Learning is necessary when someone acquires information in a completely new field of knowledge, which means the Mechanic Learning happens and storage information in an arbitrary way, until some of these knowledges, which are relevant to the new information in the same area, exist in the cognitive structure and can be used as subsumers, even they are least developed. As soon as the learning starts to be meaningful these first subsumers will become more elaborated and inclusive.

\subsection{Conditions to The Occurrence of The Meaningful Learning}

To understand the existent conditions in the Meaningful Learning is necessary to remember the process essence, in other words it is required to know that this kind of learning is the one in which the symbolically expressed ideas are related in a substantive way and not arbitrarily to what the student already knows.

Knowing this, we can confirm that the first condition to the Meaningful Learning occurrence is that the material to be learned must be "potentially meaningful", which means it 
must be relatable (in a non-arbitrary and non-literal way) to the student's cognitive structure. To satisfy this condition, we need to take in account another two conditions. First of all, the learning material (that are books, textbooks or video classes) must have logical meaning. Secondly, the individual must have in its cognitive structure relevant anchors-ideas in which this material can be associated, that is it must have suitable subsumers available ${ }^{17}$.

Besides to the potentially meaningful material, the second condition to be satisfied is that the student must demonstrate a predisposition to meaningfully learn, to relate the material to their cognitive structure in a substantive and non-arbitrary way. This implies saying that if the student's intention is simply to memorize the content, the learning process will be mechanic.

Once these conditions are satisfied the occurrence of the Meaningful Learning will be possible. What turns the comprehension of a concept or a proposition genuine and enables the possession of precise and clear meanings, not only vague ideas about the content. The evidence that Meaningful Learning happens is the individual mastering well-developed and well differentiated meanings, with a high level of discrimination, in a way that they are able to transfer this knowledge clearly, simply and precisely to another person. Nonetheless, when testing the comprehension in traditional tests, asking to be answered the special attributes from a concept, we can obtain mechanic and memorized answers. The ideal would be elaborate questions in a new and non-familiar manner. Indeed, the tests should be differently phrasing and the problem's context would also have some differentiated aspect, to demand the maximum transformation of the acquired knowledge, evidencing that the student learned in a meaningful way.

\subsection{Oblivion Assimilation}

To understand how the meaning acquisition and organization process works Ausubel proposes the Assimilation Theory, where " $\mathrm{a}$ " is a new knowledge that can be a concept, proposition or a formula, for an example; and "A" is a specifically relevant subsumer to the Meaningful Learning of "a".

The assimilation is a process that occurs when a potentially meaning knowledge a is assimilated under a more inclusive idea or concept A, already existing in the cognitive structure. In this interaction the new information is modified, transforming itself into a'; while the subsumer concept A also acquires new meanings, converting itself into A'. Besides to be modified, a' and A' remain related as co-participants of a new unit a'A'. This interactional product is called as modified subsumer ${ }^{18}$.

Taking as an example the force knowledge, if a student needs to learn the nuclear force concept, which is a short range force, they would use the subsumer force to give meaning to the new information to be learned. Thus, this new concept would acquire meaning to the student, but also the general force concept that he already had would be modified and would become more inclusive, because now its concept would include short range forces.

This assimilation besides having an explanatory value to the learning, it also has a facilitating effect on the retention. During a certain time period the information remains dissociable as individual entities, the interactional product a' A' still remains dissociable in A' and a', favoring the retention of new information a'.

On other hand, this new information become spontaneously and progressively less dissociable from its subsumers, until they are no longer available, on other words until they would be no longer reproducible as individuals entities. In this stage, it is reached the degree of zero dissociability, and A'a' is simply diminished to A'. To this process is given the name Oblivion Assimilation. This happens because we are subjected to a reductive trend of the 
cognitive organization, which makes that only more general and stable ideas, concepts and propositions be retained ${ }^{19}$.

It is important to highlight, however, that the Oblivion Assimilation doesn't make that new knowledge be totally forgotten; the subsumer that was modified will not return to its original format. The final remainder from the Oblivion Assimilation is not A how it used to be in the principle, but A'. Which means to say that there isn't forgetfulness of a', but actually part of this new knowledge is oblitared into A'.

Therefore, while in the Mechanic Learning the forgetfulness is quick and total, in the Meaningful Learning the forgetfulness is residuary, which means the forgotten knowledge is incorporated to the subsumer, there is a residual of it in the subsumer. Ergo, initially the Meaningful Learning advantage over the mechanic is in the comprehension, the meaning and the capacity of deal with new situations. However, posteriorly, the advantage is also manifested in the higher capacity of retention and the possibility to relearn something that hasn't been totally forgotten.

\section{LCPBSE As a Meaningful Learning Facilitator}

After exploring and understanding better the theory by David Ausubel, it still remains a question: How to improve the learning of an Engineering student? We showed in this paper the different advantages from Meaningful Learning in comparison to the Mechanic Learning. So, a way to improve this learning process would be promoting the Meaning Learning among the students, noticed that many of them are still not able to abandon old learning habits that are little efficient.

There are some variables that can help the Meaningful Learning proposed by Ausubel. Some instructional resources can be used, such as the progressive differentiation. To use this resource the instructor must initially map the curricular content in way to identify what is important and what is secondary. After that, the teaching must begin with the most general aspects of the content, which will be progressively differentiated in terms of detail and specificity. It is also possible to use the integrative reconciliation as a facilitative Meaningful Learning strategy. In this principle the instruction must explore the relation between the ideas, pointing important similarities and differences and reconciling actual or apparent discrepancies ${ }^{20}$.

There are some other facilitative strategies proposed, such as a sequential organization of teaching content, in which the topics are sequenced in terms of natural hierarchical dependences. Previous organizers can also be used, proposed by Ausubel himself, they can help on the Relationship and discrimination among the previous knowledges and the new ones that will be presented. Besides those, there are still another resources, just as conceptual maps, $\mathrm{V}$ diagrams and collaborative activities ${ }^{20}$.

Nevertheless, to guarantee the Meaningful Learning is important to focus on the variable that influence the most on its occurrence: the existence of specifically relevant previous knowledge. By way of explanation, to facilitate the Meaningful Learning is necessary to guarantee that the students have some previous knowledges, some specific subsumers that will be used as anchorage to the new content. It is precisely what LCPBSE has been doing.

The ministered classes by the Program accomplish the role of developing the subsumers that are necessary to learn significantly. Many academics enter on the University without having the basic competencies and abilities demanded in a third level course. Without these fundamentals it is difficult to comprise and relate the new knowledges, even that some of these strategies are used to promote the learning. Thus, the LCPBSE has the function of differentiate the subsumers, letting them more elaborated, more embracive, stable, inclusive 
and richer in meanings. In this manner the cognitive structure will be more capable of giving meaning to the new information.

The program achieve this objective through three procedures: the relevant prerequisites identification, the students' previous knowledge identification and the consolidation of the little elaborated subsumers.

\subsection{Identification of Relevant Prerequisites}

To guarantee this action effectivity, first of all the LCPBSE is worried in identify which knowledges are prerequisites to the first subjects of University. However, to identify what is a prerequisite, it is necessary to know what is taught on the University graduation program. Thus, monitors and teachers from LCPBSE are periodically mapping the programmatic content from Calculus 1, which is showed on Table 1.

Table 1. Calculus 1 Content.

\begin{tabular}{|c|c|}
\hline & Programmatic Content from Calculus 1 \\
\hline Limits & $\begin{array}{l}\text { - Instantaneous velocity. Limit idea. Definition of limit and conti- } \\
\text { nuity. properties }\end{array}$ \\
\hline & $\begin{array}{l}\text { - Limit side. Theorem of the intermediate value. The confrontation } \\
\text { theorem. }\end{array}$ \\
\hline & - Compound limit. Trigonometric fundamental limit. \\
\hline & - Limits on infinity. Asymptotes. The number $e$. \\
\hline Derivative & $\begin{array}{l}\text { - Definition of derivatives and differentials. Geometric interpre- } \\
\text { tation of the derivative. Derived and derived function of higher } \\
\text { order. Derivability and continuity. }\end{array}$ \\
\hline & - Derived from elementary functions. Derivation rules. \\
\hline & - Chain rule. Implicit derivation. Derivative of the inverse function. \\
\hline & - Rule of the l'Hôspital. \\
\hline & - Rates of change. Related rates. \\
\hline & $\begin{array}{l}\text { - Relative and absolute extremes. Monotone functions. Extreme } \\
\text { value method. }\end{array}$ \\
\hline & - Rolle's theorem. Theorem of the mean value and applications. \\
\hline & - Growth and decreasing intervals. First derivative test. \\
\hline & - Concavity and inflection points. Second derivative test. \\
\hline & - Optimization problems. \\
\hline & - Construction of graphs. \\
\hline & $\begin{array}{l}\text { - Applications of the derivative of the exponential function: popu- } \\
\text { lation growth, radioactive decay and Newton's cooling law. }\end{array}$ \\
\hline & - Primitive. Immediate primitives. EDO's and primitives. \\
\hline Integral & - Integral. Area problems. Functions given by integral. \\
\hline & $\begin{array}{l}\text { - Properties of integral. Theorem of the mean value for integrals. } \\
\text { Fundamental Theorem of Calculus. }\end{array}$ \\
\hline & - Change of variable. \\
\hline & - Integration by parts. \\
\hline & - Area between curves. Job. Arc length. \\
\hline & - Volume. \\
\hline & - Surface area of a solid of revolution. Hydrostatic pressure. \\
\hline
\end{tabular}


74 ISSN: 2358-1271. Int. J. of Alive Eng. Educ. (IJAEEdu). (Online). Goiânia, v. 4, n. 2, p. 65-82, July/Dec. 2017.

Analyzing the Table 1 it is possible to identify which perquisites are the most important. Based on that, the LCPBSE's team elaborated a class schedule, in which five major thematic axes are approached:

- Arithmetic and Algebras fundamentals;

- Intervals and Inequalities;

- Functions;

- Geometry; and

- Trigonometry.

In each thematic axe is taught what is more important to the student to learn Calculus 1. At this first stage, the LCPBSE occupies itself identifying which are the relevant subsumers (concepts, propositions and key ideas) to the learning of the content to be taught, the ones that the student should have in its cognitive structure to meaningfully learn.

\subsection{Identification of Student's Previous Knowledge}

Before start teaching, the LCPBSE worries in identifying which knowledge the academics have available in their cognitive structure, in other words which subsumers are well developed and which are little elaborated. In order to do that, the Program applies a discursive test containing ten questions, contemplating content of the five thematic axes previously presented, this test has a two hours duration. The test is applied and corrected before the beginning of LCPBSE's classes. Thus, the mistakes and difficulties can be mapped, so during the classes the aspects less known by the students can be worked more carefully.

This stage is fundamental to diagnose what the students already know and to verify among the specifically relevant subsumers which are the ones not available in the Engineering student's cognitive structure.

\subsection{Consolidation of Less Elaborated Subsumers}

After all the previous procedures are fulfilled, the LCPBSE perform the expositive lectures to consolidate the poor-differentiated subsumers. This process characteristic is the meanings sharing. The Professor presents to the students the meanings already academically accepted and stimulate the apprentice to give the learned meanings back. If what was captured is still not accepted, the Program's Professor must present these knowledges in another way. Then, the academics are stimulated again in order to outsource what they have learned.

The process continues until the meanings from the educative material that the student captured are the ones the Professor wanted to lecture. This social interaction allows that these knowledges sharing exists. The expositive lectures are planned and oriented in order to a meanings negotiation between student and Professor happens.

\section{The Impact of LCPBSE on Approval}

Some statistical studies have been showing the success of the Program on the students' performance in Calculus 1. During the years of 2013, 2014 and 2015 it was calculated the approval's percentage from students that attended LCPBSE and from the ones that did not. The data are separated by Engineering Courses. The Graphics 1 to 13 include the average approval percentage from the three specified years. 


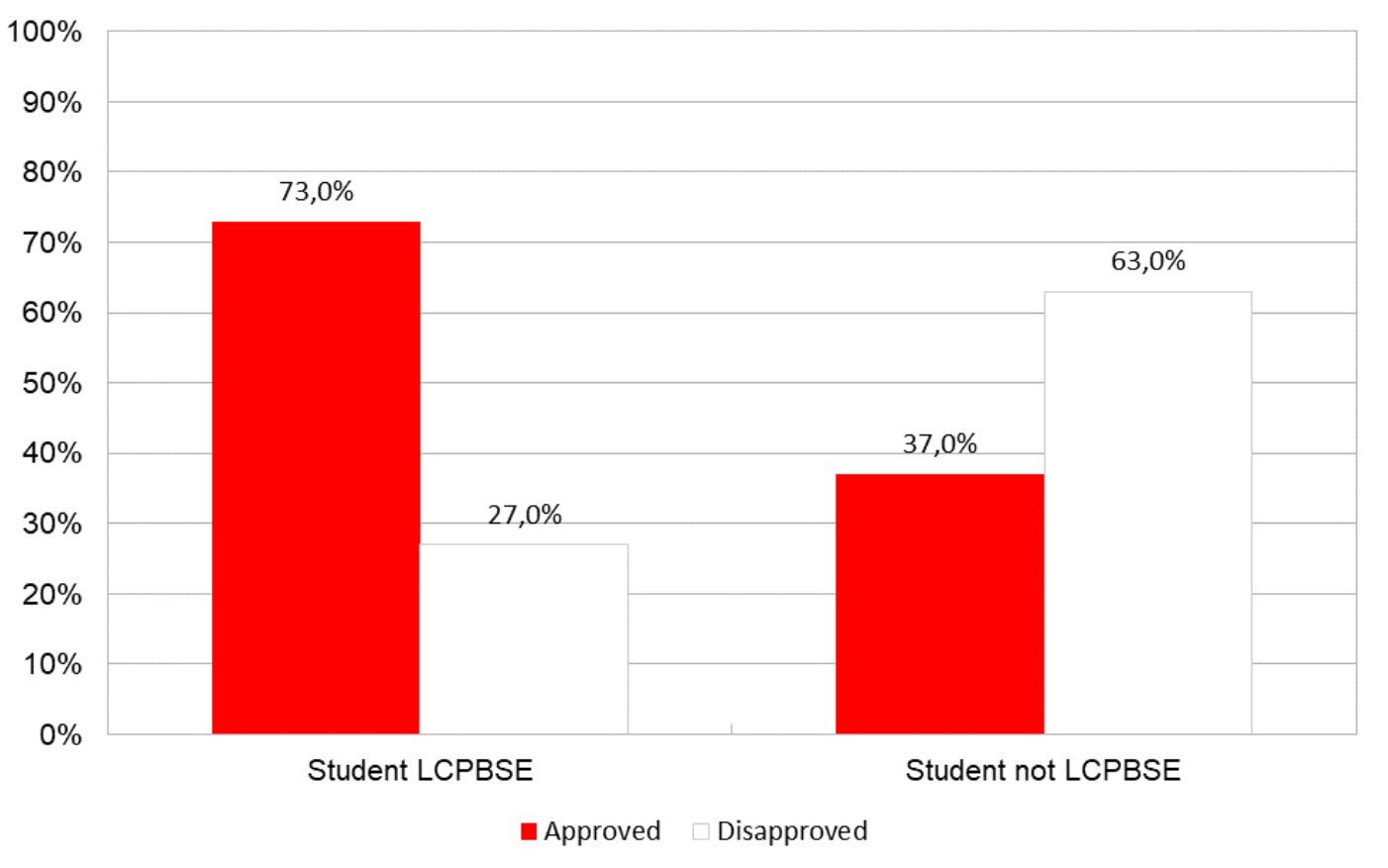

Graphic 1. Civil Engineering.

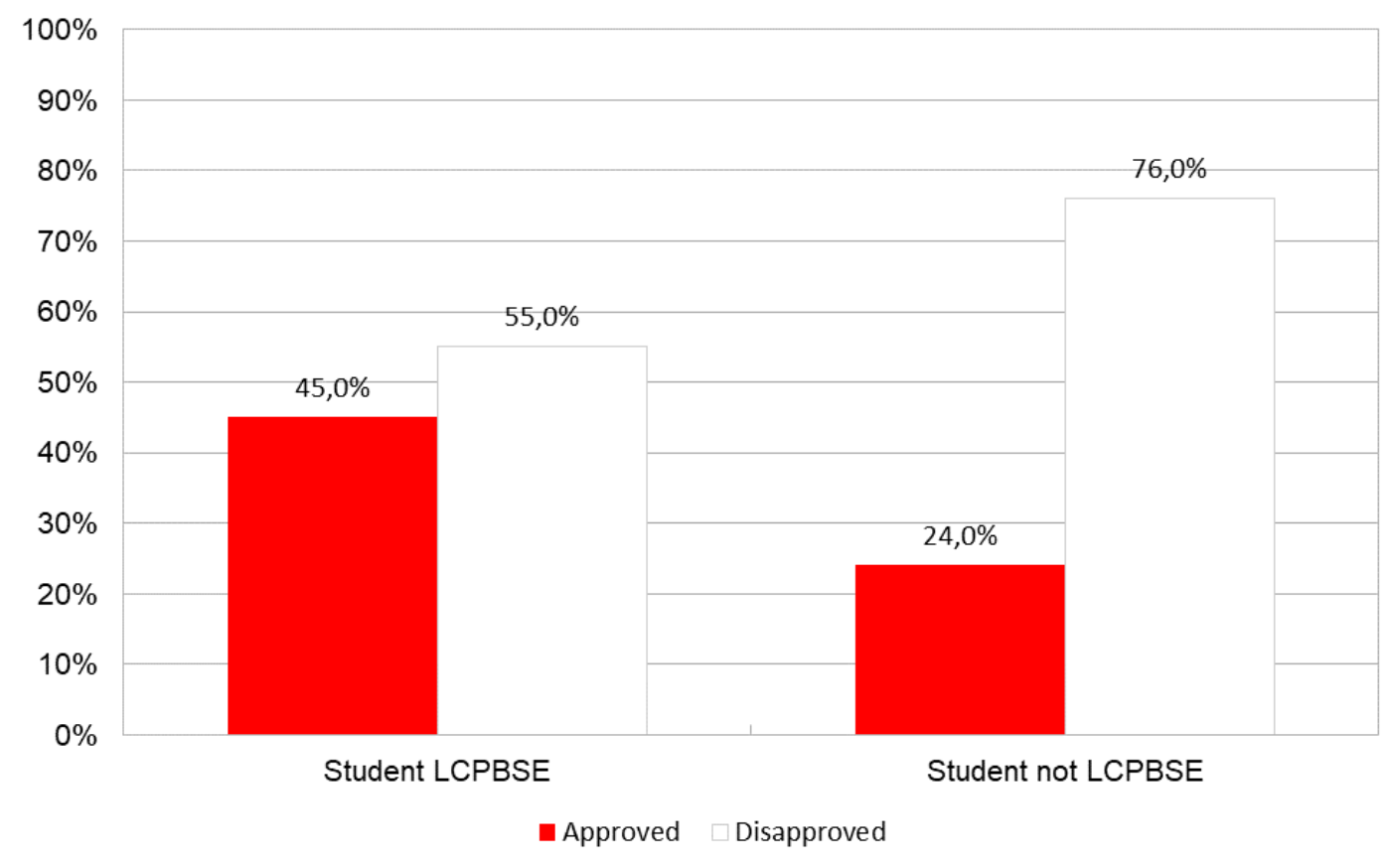

Graphic 2. Biomedical Engineering. 
76 ISSN: 2358-1271. Int. J. of Alive Eng. Educ. (IJAEEdu). (Online). Goiânia, v. 4, n. 2, p. 65-82, July/Dec. 2017.

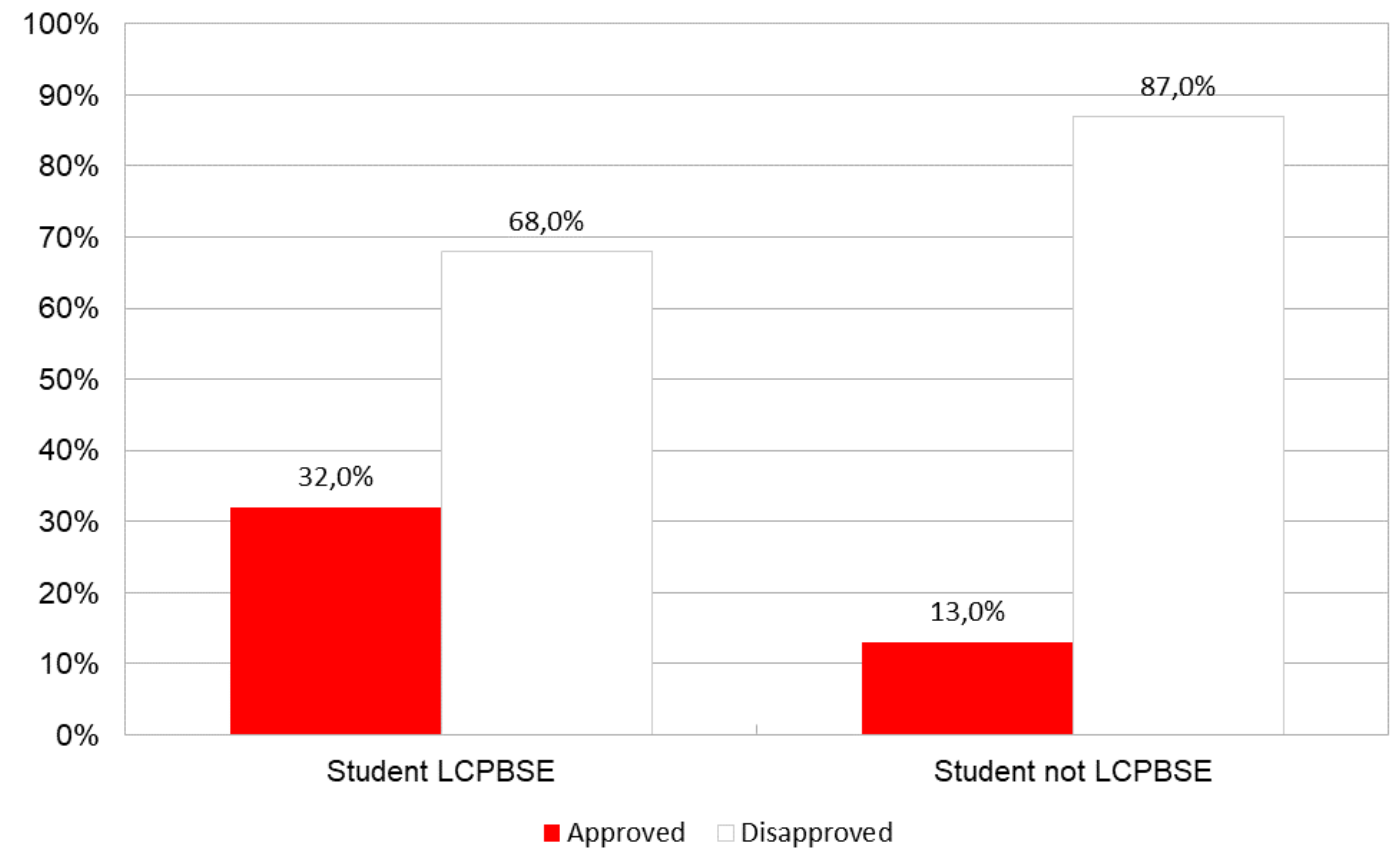

Graphic 3. Food Engineering.

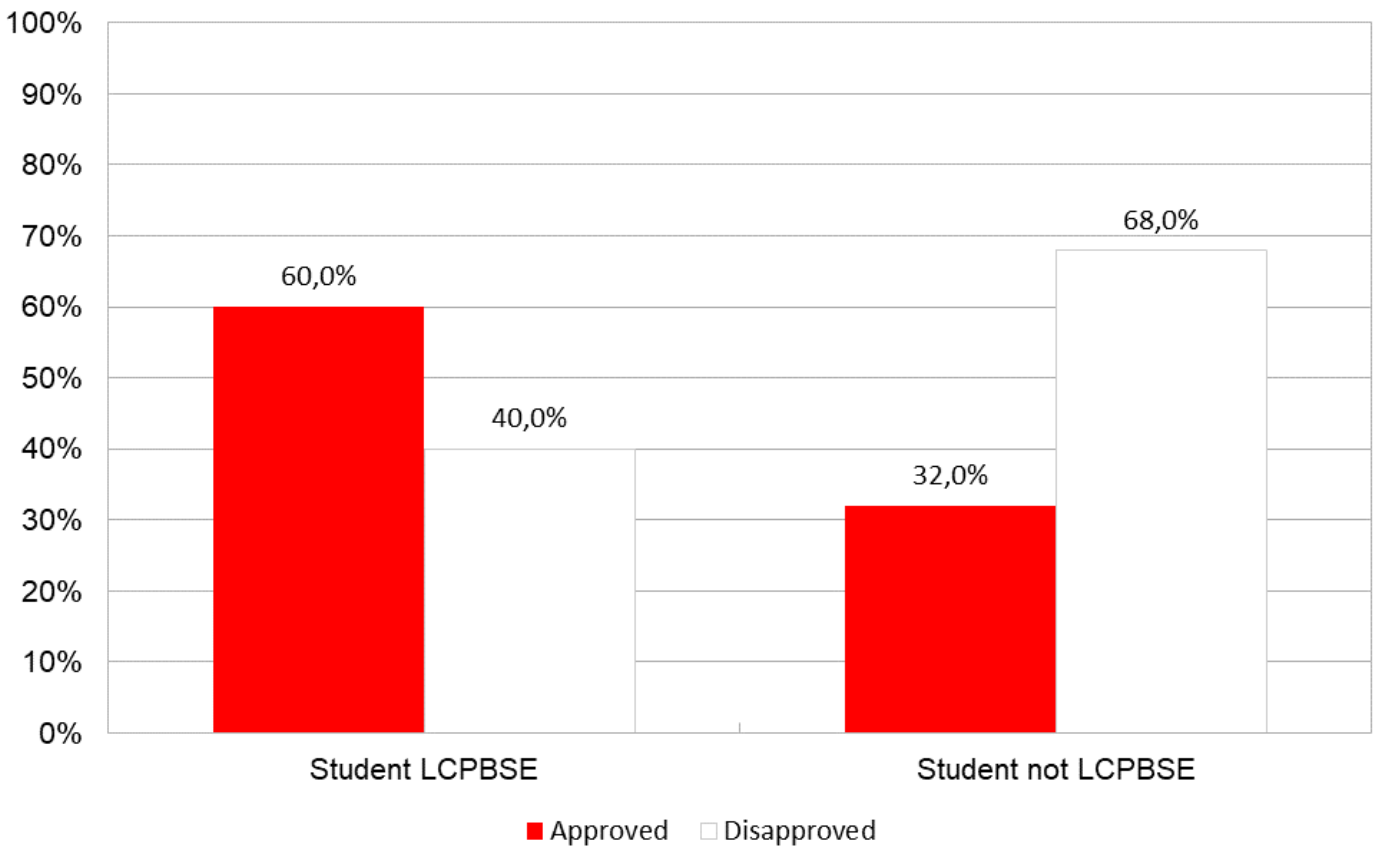

Graphic 4. Computer Engineering. 
ISSN: 2358-1271. Int. J. of Alive Eng. Educ. (IJAEEdu). (Online). Goiânia, v. 4, n. 2, p. 65-82, July/Dec. 2017.77

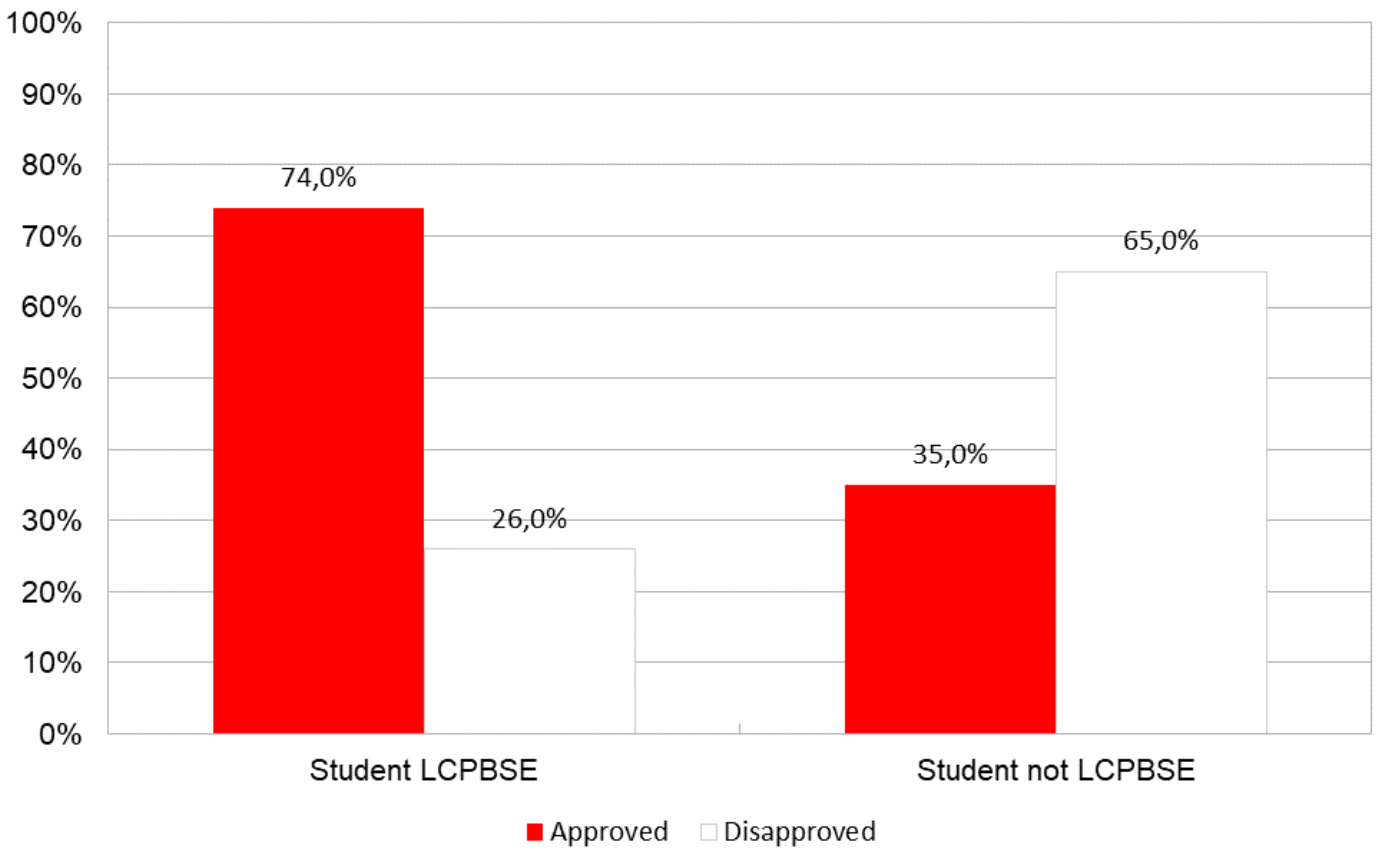

Graphic 5. Electrical Engineering.

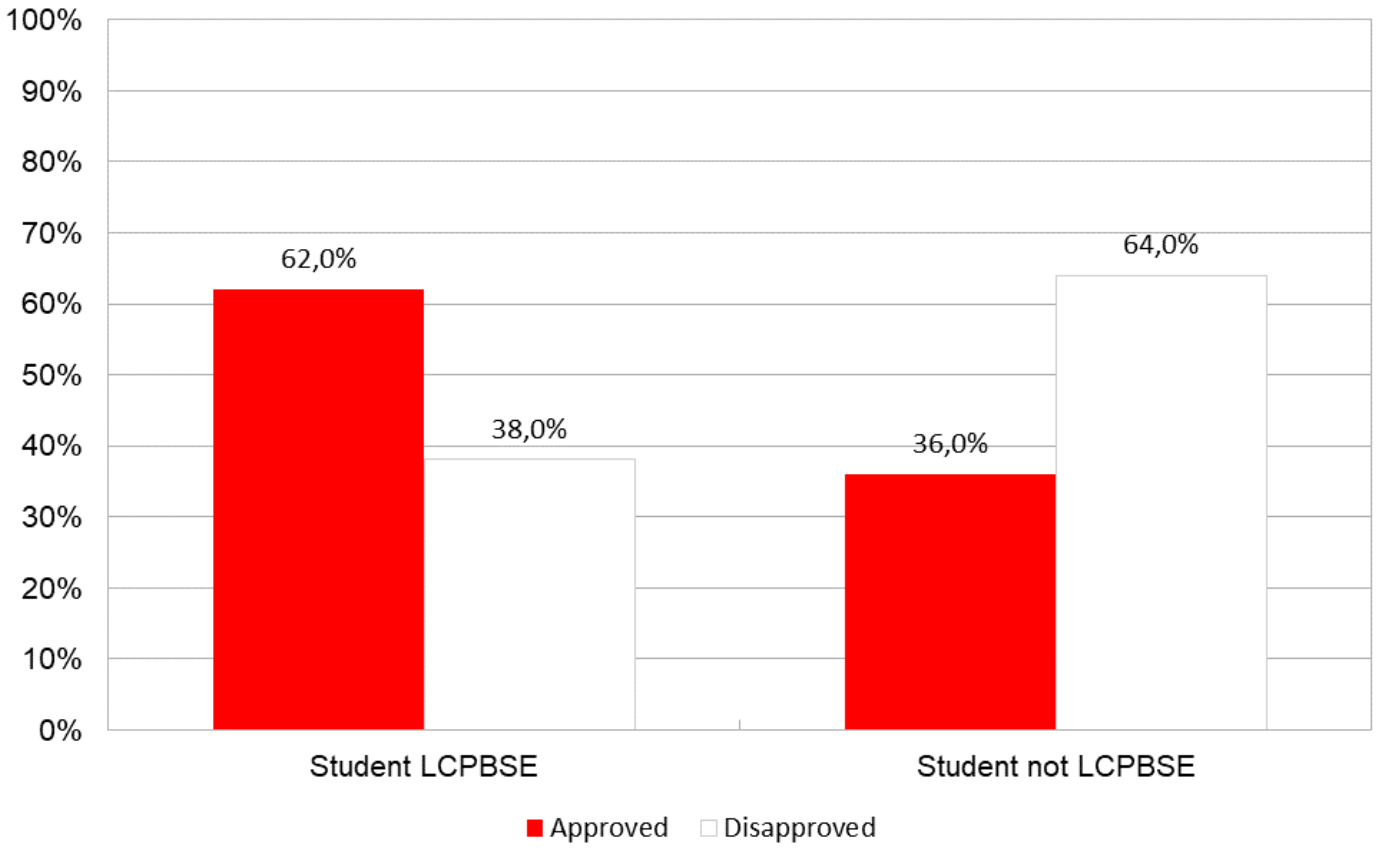

Graphic 6. Materials Engineering. 
78 ISSN: 2358-1271. Int. J. of Alive Eng. Educ. (IJAEEdu). (Online). Goiânia, v. 4, n. 2, p. 65-82, July/Dec. 2017.

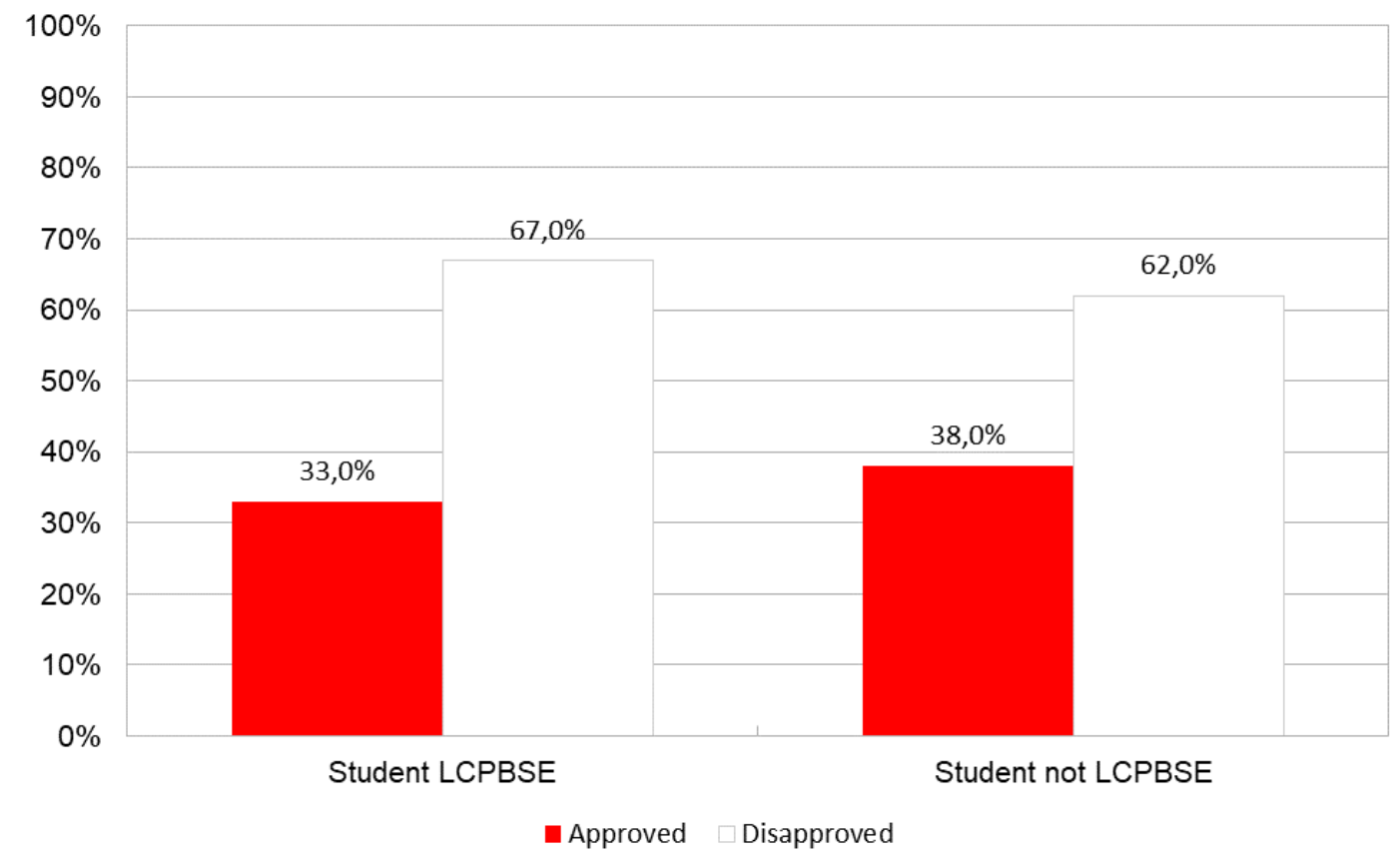

Graphic 7. Railway Engineering.

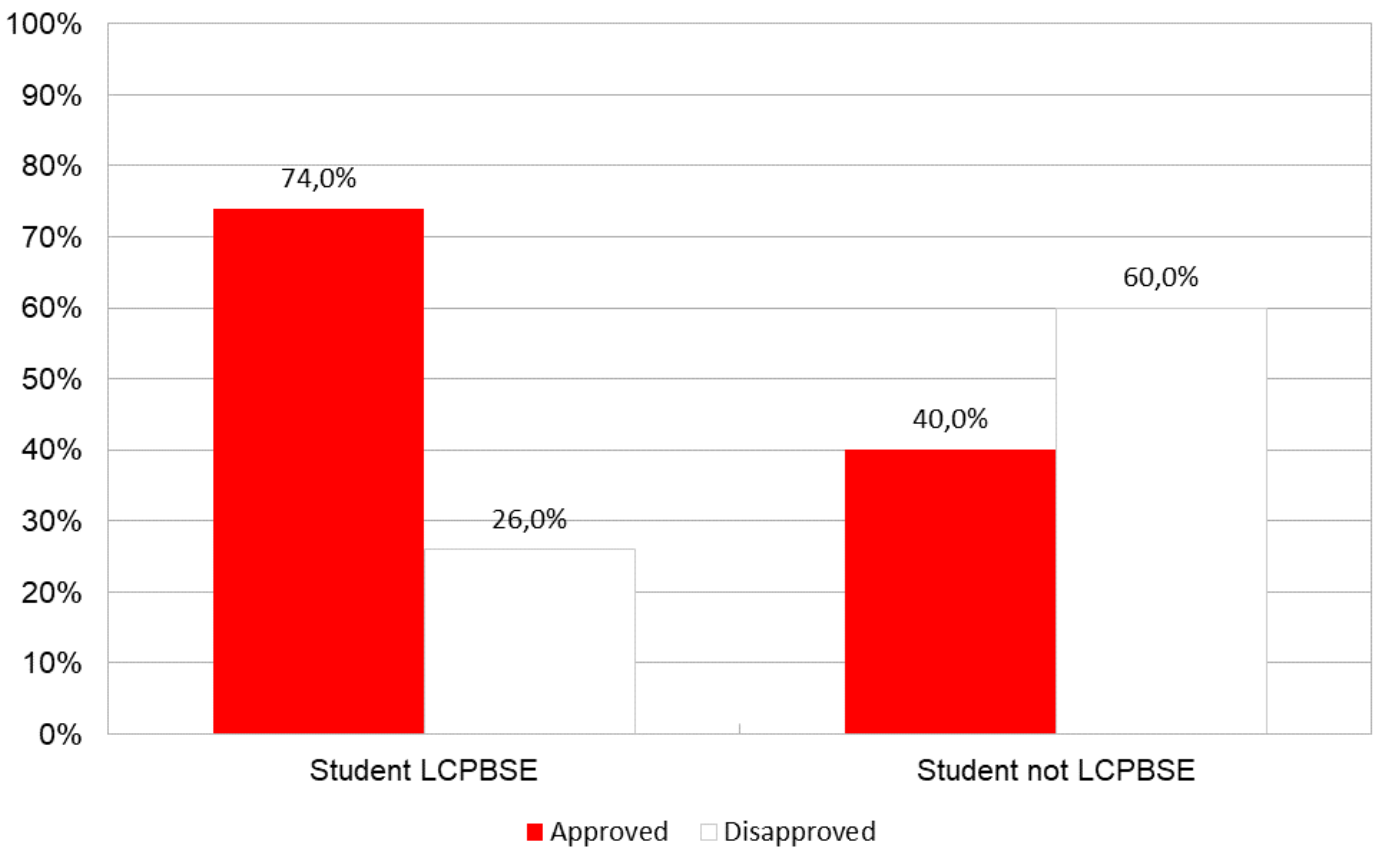

Graphic 8. Chemical Engineering. 
ISSN: 2358-1271. Int. J. of Alive Eng. Educ. (IJAEEdu). (Online). Goiânia, v. 4, n. 2, p. 65-82, July/Dec. 2017.79

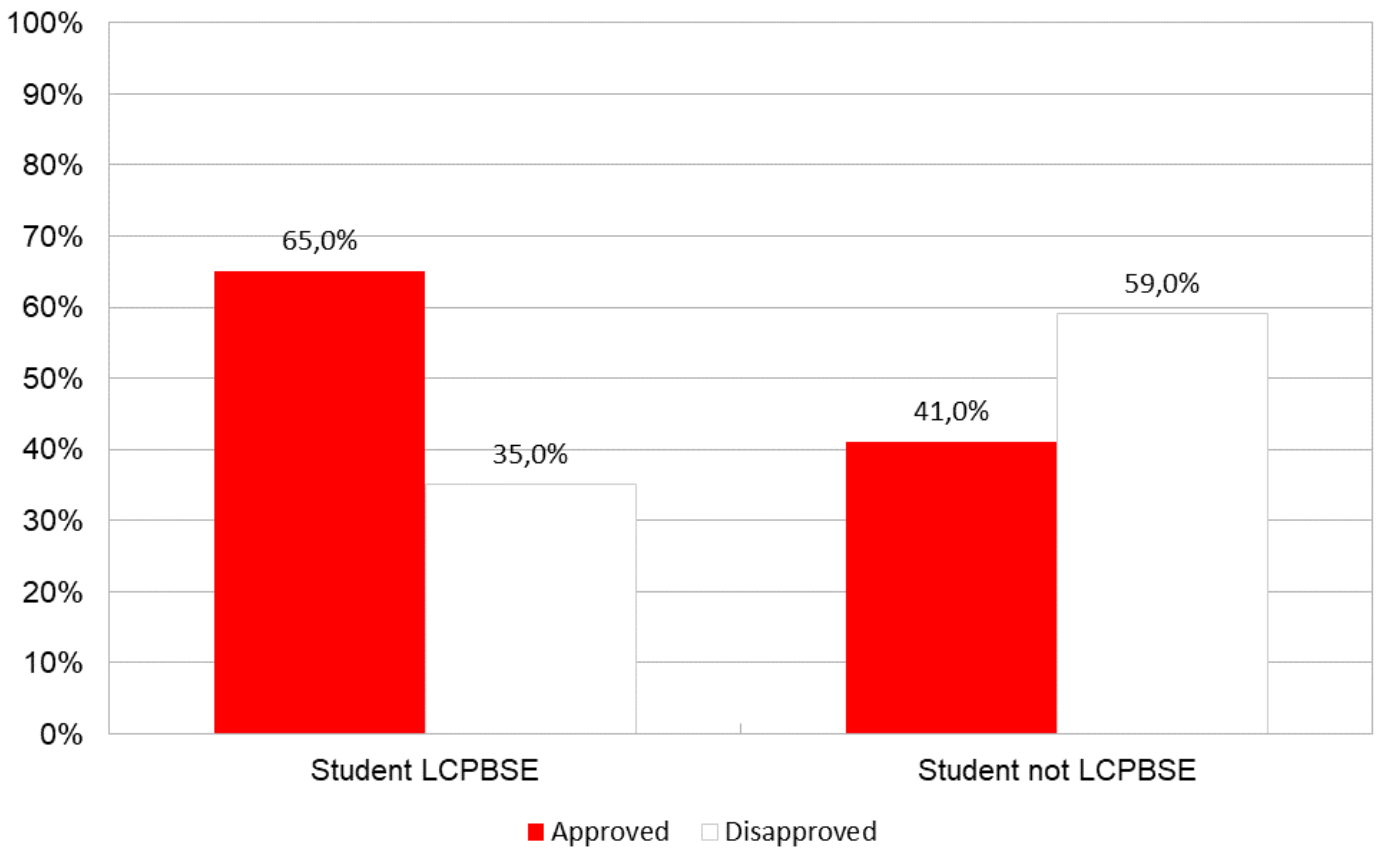

Graphic 9. Mechanical Engineering.

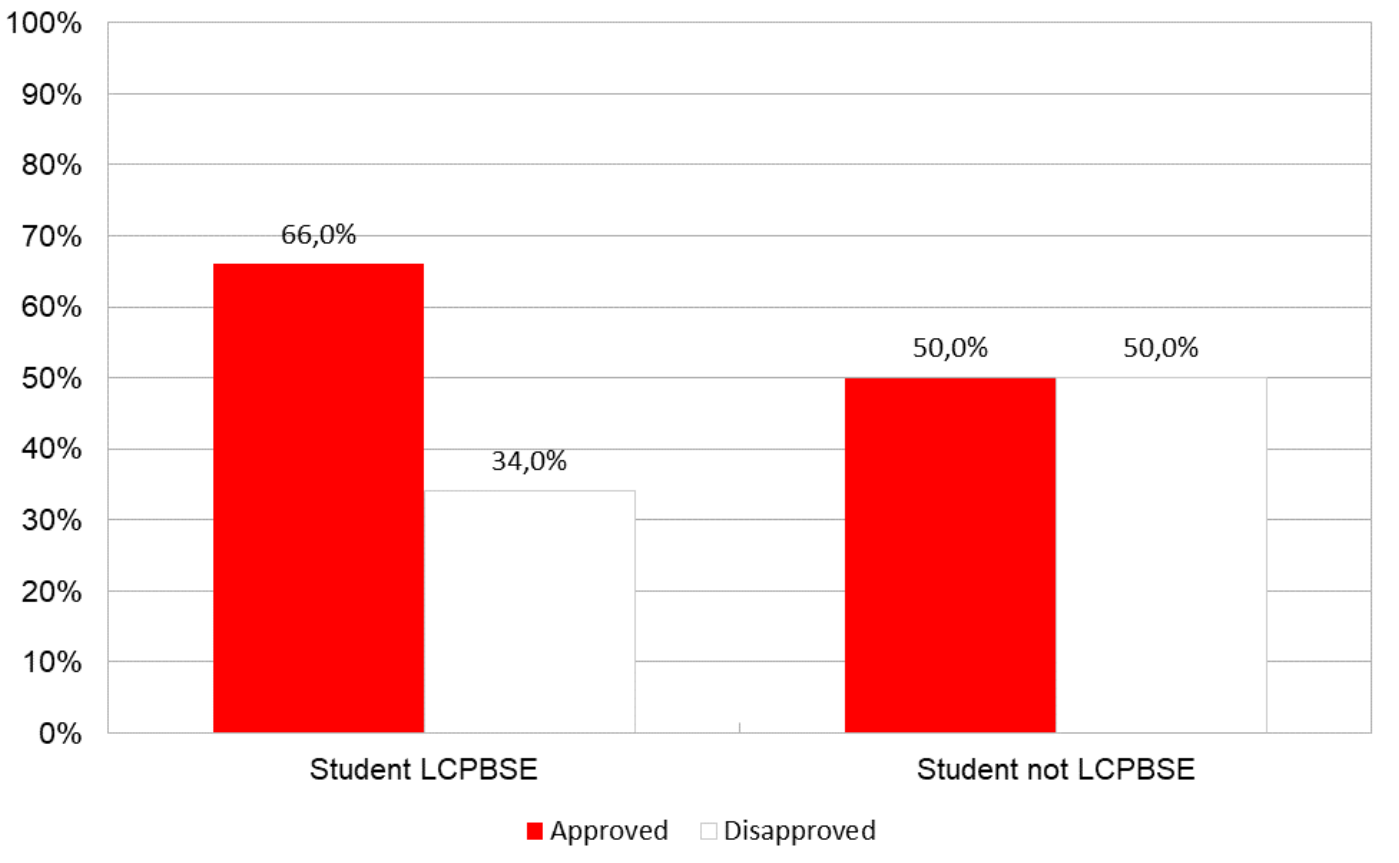

Graphic 10. Sanitary Engineering. 
80 ISSN: 2358-1271. Int. J. of Alive Eng. Educ. (IJAEEdu). (Online). Goiânia, v. 4, n. 2, p. 65-82, July/Dec. 2017.

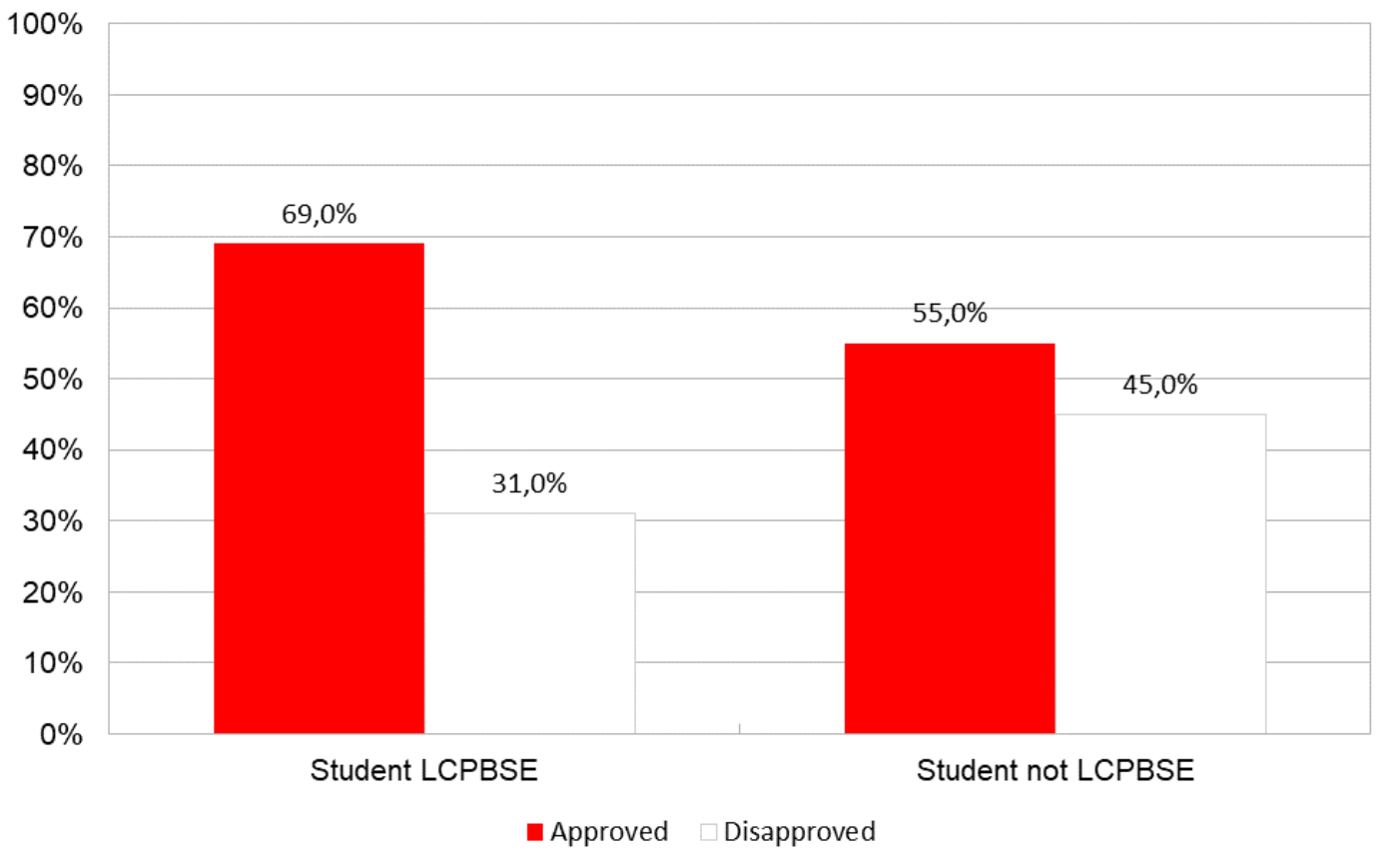

Graphic 11. Naval Engineering.

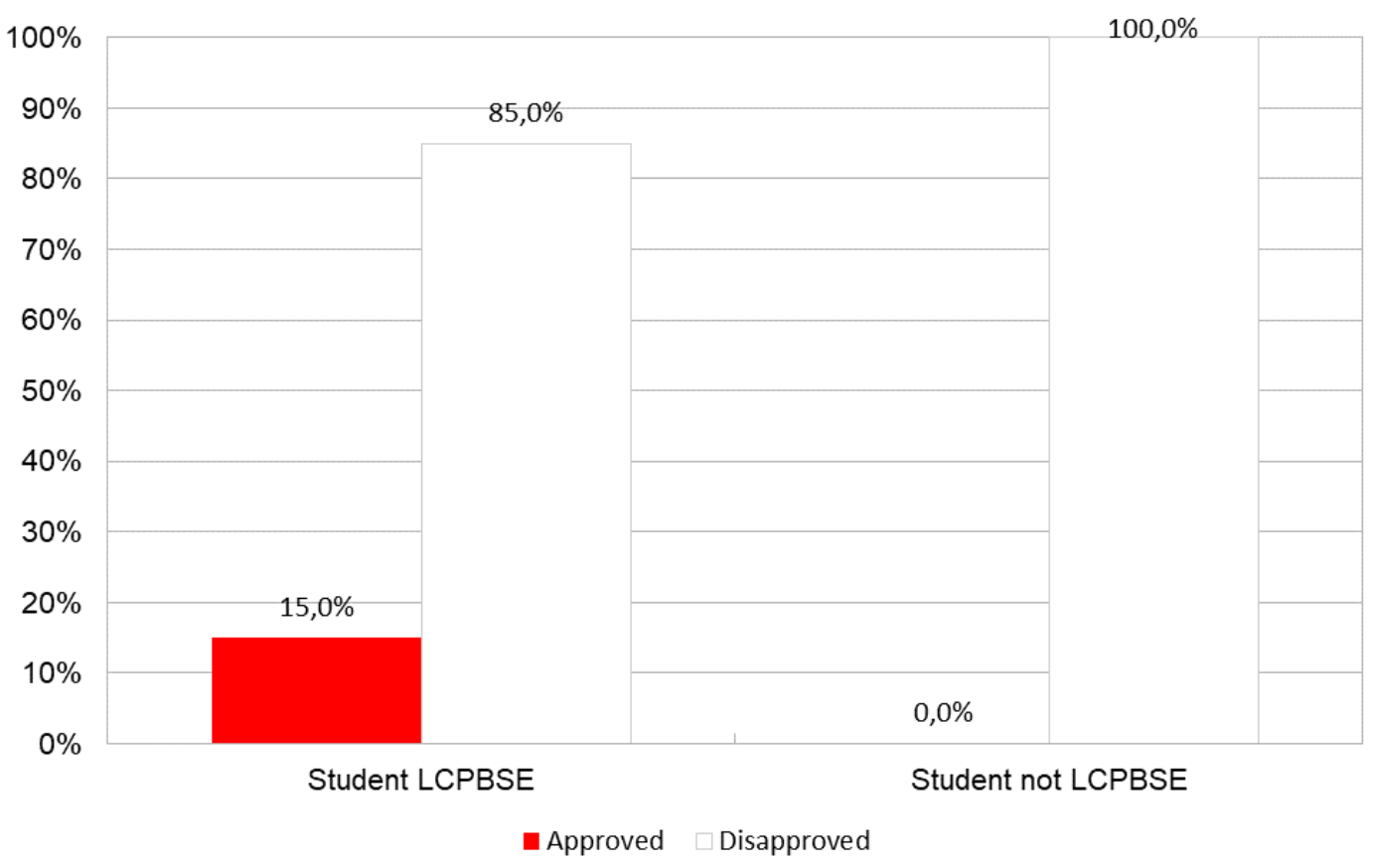

Graphic 12. Telecommunication Engineering.

As can be seen, except for Railway Engineering, all the other major Courses present a higher approval percentage to the students that attended LCPBSE. Railway Engineering 
was the only one that fled the pattern, but its percentage difference was not very significant. All the twelve Engineering Courses along their approval percentage for students that attend LCPBSE and the ones who didn't, can be resumed on the Graphic 13 below.

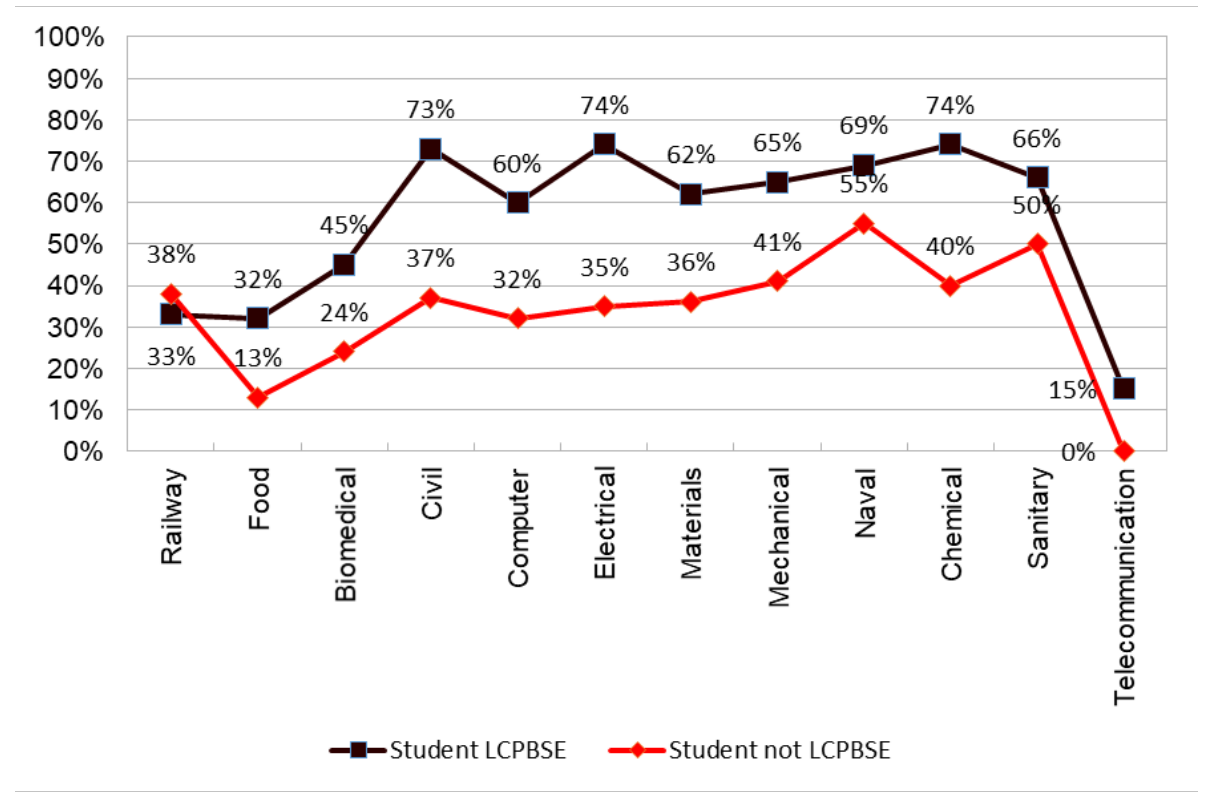

Graphic 13. Percentage of approval of Engineering.

\section{Final Considerations}

This paper sought to explain the learning's epistemological mechanism that the LCPBSE use to improve the approval indexes. Among the researched bibliography we verified that this mechanism can be explained by the Meaningful Learning Theory, whose main idea consist into affirm that the variable that influence the most on the learning is the student's previous knowledge; so it's the Professor responsibility to discover it and teach it accordingly.

Based on this principle and knowing that not all the academics go to college possessing an efficient educational foundation, the LCPBSE fulfills the function of developing the subsumers, making them more differentiate, elaborated and inclusive, so that they can serve as anchorage to the new information. Without these subsumers stable and available on the cognitive structure the student is not able to meaningfully learn.

The Higher Education drop-out is a loss not only for the student, but also for all involved agents. Amid the great social losses that the evasion represents it is important to join forces to guarantee the academic's permanence in Higher Education. In this sense, we verified that the subsumers' development is a strategy used by LCPBSE that has been successfully working. This strategy can also be applied in other Universities programs.

\section{Reference}

1. FILHO, R. L. L. S. et al. A evasão no ensino superior brasileiro. Cadernos de pesquisa, v. 37, n. 132 , p. $641-659,2007$. 
2. BAGGI C. A. S.; LOPES, D. A. Evasão e avaliação institucional no ensino superior: uma discussão bibliográfica. Avaliação: Revista da Avaliação da Educação Superior, v.16, n.2, p.355374, ISSN 1414-4077, 2011.

3. VALENTE, P. S. et. al. How An Educational Program Can Improve Learning for An Engineering Student. In: DEUS JÚNIOR, G. A. de et. al. (Org.). Alive Engineering Education Transforming and Innovating Engineering Education. Goiânia: Cegraf UFG, 2017. cap. 38, p. 329-338. Available: <https://icaeedu.emc.ufg.br/p/22211-alive-engineering-educationtransforming-and-innovating-engineering-education $>$. Date of access: 30 Mar. 2018.

4. DA SILVA, G. C. Análise de evasão no ensino superior: uma proposta de diagnóstico de seus determinantes. Avaliação: Revista da Avaliação da Educação Superior, v. 18, n. 2, 2013.

5. LOBO, M. B. C. M. Panorama da evasão no ensino superior brasileiro: aspectos gerais das causas e soluções. Associação Brasileira de Mantenedoras de Ensino Superior. Cadernos de pesquisa, n. 25, 2012.

6. RODRIGUES, M. E. Behaviorismo: mitos, discordâncias, conceitos e preconceitos. Educere et Educare, v. 1, n. 2, p. 141-164, 2007.

7. SANTOS, J. A. S. Teorias da Aprendizagem: comportamentalista, cognitivista e humanista. Revista Cientifica Sigma, v. 2, n. 2, p. 97-111, 2006.

8. FERRACIOLI, L. Aprendizagem, desenvolvimento e conhecimento na obra de Jean Piaget: uma análise do processo de ensino-aprendizagem em Ciências. Revista Brasileira de Estudos Pedagógicos, v. 80, n. 194, 2007.

9. CACHAPUZ, A; PRAIA, J; JORGE, M. Da educação em ciência às orientações para o ensino das ciências: um repensar epistemológico. From Science Education to Science Teaching: anepsitemological rethinking. Ciência \& educação, v. 10, n. 3, p. 363-381, 2004.

10. SIMÕES, F. et al. Desenvolvimento do auto-conceito pela tutoria pedagógica por crianças do primeiro ciclo. Revista Semestral da Associação Brasileira de Psicologia Escolar e Educacional, v. 12 , n. 2, p. 327-336, 2008.

11. MOREIRA, M. A. A teoria dos campos conceituais de Vergnaud, o ensino de ciências e a pesquisa nesta área. Investigações em ensino de ciências. v. 7, n. 1, p. 7-29. Porto Alegre, 2002.

12. TAVARES, R. Aprendizagem Significativa e o Ensino de Ciências. Ciências\&cognição, v. 13, n. 1, p. 94-100, ISSN 1806-5821, 2008.

13. MANCINI, A. A. Aprendizagem Significativa: a teoria de David Ausubel. São Paulo: Centauro, 2005.

14. PELIZZARI, A. et al. Teoria da aprendizagem significativa segundo Ausubel. Revista PEC, v. 2, n. 1, p. 37-42, 2002.

15. MOREIRA, M. A. Aprendizagem Significativa: da visão clássica à visão crítica. Conferência de encerramento do V Encontro Internacional sobre Aprendizagem Significativa, Madrid, Set. 2006.

16. MOREIRA, M. A. Linguagem e Aprendizagem Significativa. Conferência de encerramento do IV Encontro Internacional sobre Aprendizagem Significativa, Maragogi, AL, Set. 2003.

17. VASCONCELOS, C; PRAIA, J. F; ALMEIDA, L. S. Teorias de aprendizagem e o ensino/aprendizagem das ciências: da instrução à aprendizagem. Psicologia Escolar e Educacional, v. 7, n. 1, p. 11-19, ISSN 2175-3539, 2003.

18. MOREIRA, M. A. Aprendizagem significativa, organizadores prévios, mapas conceituais, diagramas V e unidades de ensino potencialmente significativas. Pontifícia Univercidade Católica do Paraná, 2013.

19. GOMES, A. P. et al. A Educação Médica entre mapas e âncoras: a aprendizagem significativa de David Ausubel, em busca da Arca Perdida. Revista Brasileira de Educação Médica, v. 32, n. 1, p. 105-111, ISSN 0100-5502, 2008.

20. NOVAK, J. D. Meaningful Learning: The Essential Factor for Conceptual Change in Limited or Inappropriate Propositional Hierarchies Leading to Empowerment of Learners. Science education, v. 86, n. 4, p. 548-571, 2002. 